\title{
E-Learning Tutoring System for Sijil Pelajaran Malaysia (SPM) English
}

\author{
Munirah Mohd Yusof ${ }^{1}, N g$ Lee Wah ${ }^{1}$, Rozlini Mohamed ${ }^{1}$ and Muhaini Othman ${ }^{1}$ \\ ${ }^{1}$ Faculty of Computer Science \& Information Technology, Universiti Tun Hussein Onn Malaysia, Johor, Malaysia
}

\begin{abstract}
An E-Learning tutoring system for English (SPM) is an e-learning platform for Sijil Pelajaran Malaysia English subject. E-learning is a web based application that supports the delivery of learning, skills and knowledge related to the English subject in SPM. E-learning use the technology to enable people to learn anytime and anywhere. Besides, it is developed with the purpose to evaluate student's performance through an online quiz. Nowadays, tuition center have a lot of students, hence insufficient time to analyze the individual performance in learning English. In addition, e-learning is able to reduce the printing cost and administrative cost at the same time reducing usage of paper and printed materials associate in learning. The system developed by using Javascript and PHP language based on system prototyping methodology. The result will produce student's performance in monthly quiz and teacher are able to monitor the performance of each students. Although the development or this e-learning is based on requirement gathered via tuition center, however it can be proposed to be by any learning center or to self-study. It is hoped that this e-learning will be able to improve student knowledge in English language and subsequently help student to obtain the best result in SPM by providing more guided references and practices.
\end{abstract}

\section{Introduction}

An E-Learning tutoring system for SPM English is an elearning platform for Sijil Pelajaran Malaysia (SPM) English. It is a web based application that supports the delivery of learning, skills and knowledge related to the English subject in SPM where it enable people to learn anytime and anywhere. E-learning tutoring system is developed with the purpose to evaluate student's performance through an online quiz. Quizzes are carried out monthly to evaluate student's English knowledge. Nowadays, tuition center have a lot of students, hence insufficient time to analyze the individual performance in learning English. In addition, e-learning is able to reduce the printing cost and administrative cost at the same time reducing usage of paper and printed materials associate in learning. The system developed by using Java Script and PHP language based on system prototyping methodology. The result will produce student's performance in monthly quiz and teacher are able to monitor the performance of each students. This system could be proposed to be used by education field such as tuition center. An e-learning tutoring system, user does not need to install any software to support and run it. End user only need to have a web browser to access the web application via internet.
The rest of this paper is organized to provide a brief explanation of e-learning and related work in Related Works section. The following section is Methodology while, in the next section will discuss on System Development. Section 5 focus on Implementation and Testing and Section 6 discuss on Evaluation. Discussion and Conclusion will be discussed in the last section.

\section{Related Works}

In recent year, the knowledge based economy has exhibited a pervasive and ever increasing ways of delivering education, which has led to dramatic changes in learning technology. As the new economy requires more people learn new knowledge and skills in a timely and effective manner, the advancement of computer and networking technologies are providing a diverse means to support learning in a more personalized, flexible, portable and on-demand manner. There radical changes in learning needs and technology are fueling a transition in modern learning in the era of the Internet, referred as e-learning [1]. 


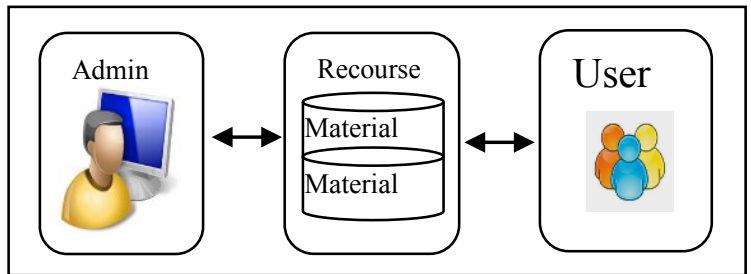

Figure 1: E-learning architecture

E-learning is the use of electronic media, educational technology and information and communication technologies (ICT) in education. E-learning includes numerous types of media that deliver text, audio, images, animation, and streaming video, and includes technology applications and processes such as audio or video tape, satellite TV, CD-ROM, and computer-based learning, as well as a local intranet or extranet and web-based learning [2]. Basically, the e-learning architecture as shown in Figure 1 are divided into three part; resources, user and administrator. Resources consist of teaching materials such as note, assessment and others. Users are instructors and learners; where instructors are the person that responsible to provide the courses and place on the internet while learners are the person that uses the courses. The administrator is an important person that responsible to manage the e-learning in a whole.

With the rapid growth in internet technology elearning implementation becomes more advanced. Internet accessibility is one of the major factors that contribute to the successful implementation of the online e-learning [3]. With the growth of Internet accessibility in various places and growth of Internet subscribers among Malaysians, it is believed that it will bring a positive element in digital lifestyle towards the usage of e-learning in Malaysia.

The very first reference to e-Learning was made way back in 1999 in the government Multimedia Super Corridor (MSC Malaysia) blueprint for Smart School Flagship Application [4] It comprised with browserbased teaching-learning materials (and related print materials) for Bahasa Melayu, English language, Science and Mathematics. In 2007, K-Perak e-Learning Cluster (KPEC) was launched to provide professional development for teachers and build e-learning capability in a cluster of five selected schools in the state of Perak. Teaching and learning content is made available to teachers through the project website, which features an interactive forum. As an initiative to support e-Learning activities Malaysian Grid for Leaning (MyGfl) was introduced to ensure conformance and best practice in elearning content and systems. One of the projects under MyGfl was Cikgu.net that launched on 2000. The portal used Malay language as a teaching medium and Cikgu.net attracted thousands of registered users. Besides that, private sector play an important role in fostering e-Learning in Malaysians schools. For instances, Smart Utusan Education Portal has been set up by Utusan Melayu Berhad contains teaching and learning material for all levels of school education. Most of the main subjects in school for instances mathematics, science and English have been covered. This initial implementation shows that e-learning been established in Malaysia and it progress not only in primary school but also in secondary school and higher institution learning.

Thus this paper based on one of the subject that studied from primary school until higher institution learning which is English. However, this study scope is on English for SPM which is for secondary school. English has known as an important second language and is widely spoken especially in the countries once colonized by United Kingdom or the United States of America [5]. It has been the aims of Kurikulum Baru Sekolah Menengah (KBSM) to extend learners English language proficiency in order to meet their needs to use English in certain situations in everyday life. Traditional English subject were conducted in class where teacher will delivered their lesson and handling exercise throughout the class session [5]. The good of this traditional method is that, students can have lesson and ask any questions face to face with their teachers, however time frame is insufficient for each lesson. Students need to study by themselves to grasp more knowledge and understanding in English subject alone. However, improving proficiency in English language through a subject called English in the school curriculum is insufficient as educational planners at the Education Ministry and teachers in schools have realized over the years [5]. Hence, e-learning can be one of the platform to help students improve their English. With e-learning, students can enrolled in virtual English class, download learning material, answer exercise and quiz to evaluate their understanding level and compare their results easily. Besides, some e-learning platform placed forum as one way for students to communicate and discuss with others students or teachers.

\section{Methodology}

The methodology used for developing an e-learning tutoring system for SPM English is system prototyping. System prototyping able to develop a simplified version of proposed system and give it to the user evaluation and feedback. After collecting the feedback from the users, the developer will reanalyze, redesign and re-implement a second prototype that correct deficiencies and add more features in order to develop a quality of system that meet user requirement [4]. In addition, Prototype Model able to identify all the system error test after received user's feedback. The model performed the analysis, design and implementation phases repeatedly in a cycle until the system is completed. The prototype model include five phases which is planning, analysis, design, system prototype and implementation. However, the prototype model may increase the complexity of the system may expand beyond original plans. Nevertheless, prototyping ensures that the end users constantly work with the system and provide a feedback which is incorporated in the prototype to result in a useable system. They are excellent for designing good human computer interface systems. The process model of the Prototype Model approach is shown in Figure 2. Section 3.1 until 3.5 will discussed on the phases in details. 


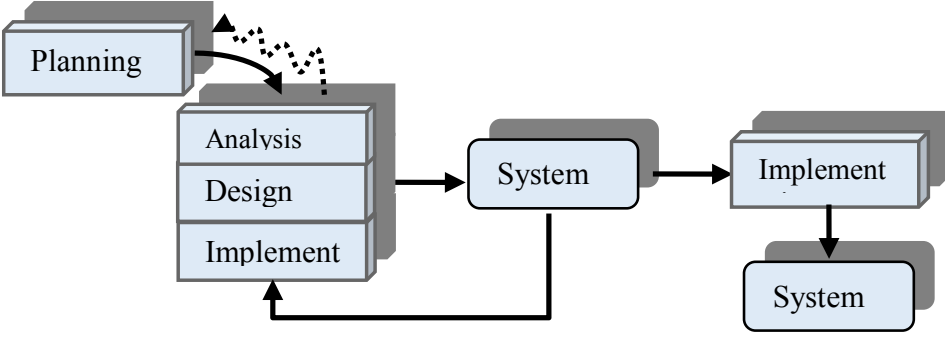

Figure 2: Prototype Model [6]

\subsection{Planning Phase}

In planning phase is to discuss the development of a project based on the given time period. The problem statement, objective, scope of system are well defined. In addition, interview with related field has been carried out to identify the problem statement and scope of system. It works as a guideline to ensure this project able to complete on time.

\subsection{Analysis Phase}

This phase will design the context diagram which showing the entities that interact with it, entity relationship diagram, data flow diagram and flow chart for every entities. The diagrams able describe the interaction among the user, proposed system and the database. In addition, interview with the owner of tuition center Pusat Tuisyen Minda Proaktif, Puan Nurul Husna Zakaria and Miss Erni asn English teacher had been done to get more information about the process of conducting the class and studies material she used during English class. Hence, the information gained from the interviewer and determine the user requirement.

\subsection{Design Phase}

In design phase, user interface and database will be designed based on the gathered information which is based on the user requirement identified on the previous phase. Input and output of the proposed system are designed as well as context diagram, entity relationship diagram and flow chart. The user interface consists of user login page for admin, teacher and students. Designing the database are using MySQL to store information of teacher, students and studies materials.

\subsection{Implementation Phase}

In implementation phase, the development of proposed system is constructed according the planning, analysis and design phase. After constructed the propose system, testing and debugging will be carried out. The testing will be conducted by allowing users to access to the system and then distributing questionnaires to gain feedback. Those feedback will be analyze to determine whether the objectives have been achieved.

\subsection{Implementation Phase}

User feedback is obtained and analyze and new action will be carried out in order to improve the system. Each prototype and design of interface may redesign and make improvement. This activity the system is believed to be able fulfill the requirements and provide the best quality to the users.

As a conclusion, by using Prototype model in the development of web based tutoring system for English SPM it will help development process more systematic.

\section{System Development}

E-Learning Tutoring System for SPM English is divided into four users; admin, teacher, student and parent. Each of this user has their own modules. User modules are built on online platform consists of six modules which are login module, tutoring module, assessment module, teacher module, parent module and result module. Tutoring and assessment module is the main part of this system used by students. In tutoring module, various notes were uploaded in order to help students learn with more leisure while assessment module help in identifying student understanding on what they learn through the answer given for several questions prepared. In teacher module learning material can be uploaded and managed so the notes will be changed in some period of time. Teacher will manage exercise and quiz materials and they can access and view student assessment result. For parents, they can access their children details and assessment result. Meanwhile, system administrator are able to register new students information and manage students details by add, delete, and update their information.

This E-Learning Tutoring System for SPM English is an alternative way for the students in for their learning purposes. It have a user friendly interface design and provides good interaction between systems and user. The system will start with login module where the user need to insert username and password to access the system after registration. After the user was authenticated, main page will be display. New student need to be registered in order to use this system. As for teacher, one of the tasks is to added quiz or exercise questions as in Figure 3. Figure 4 shows interface that allowed teacher in managing students' assessment report. If VIEW icon been clicked, it will show students results for each of the answered questions and their total assessment results. Figure 5 shows the interface of assessment results for students. Each student can only view their own results and the system stored all their previous results in database. This will help students in comparing their performance after each quiz is taken. As for Figure 6, the interface shows that parents can view all of their children' assessment report. With this, parents can observe their children performance and taken extra measures in making sure that their children will perform well in this subject. 


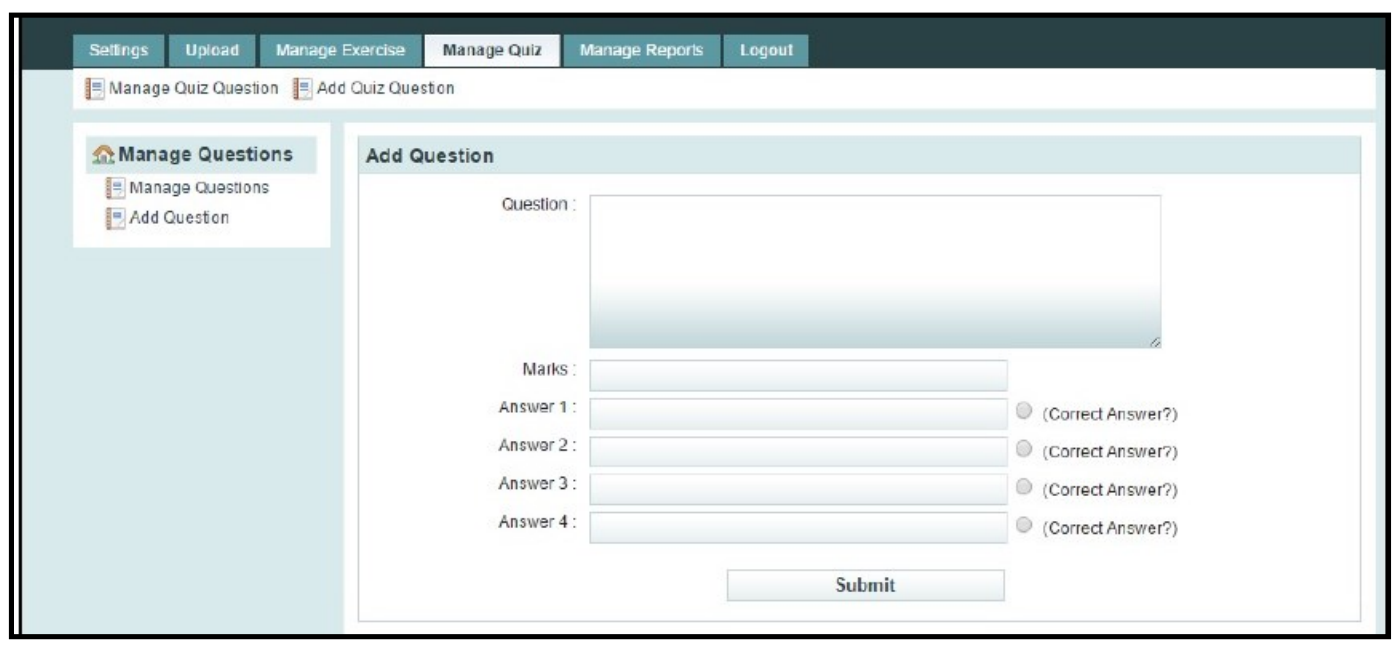

Figure 3: Adding new question for assessment module

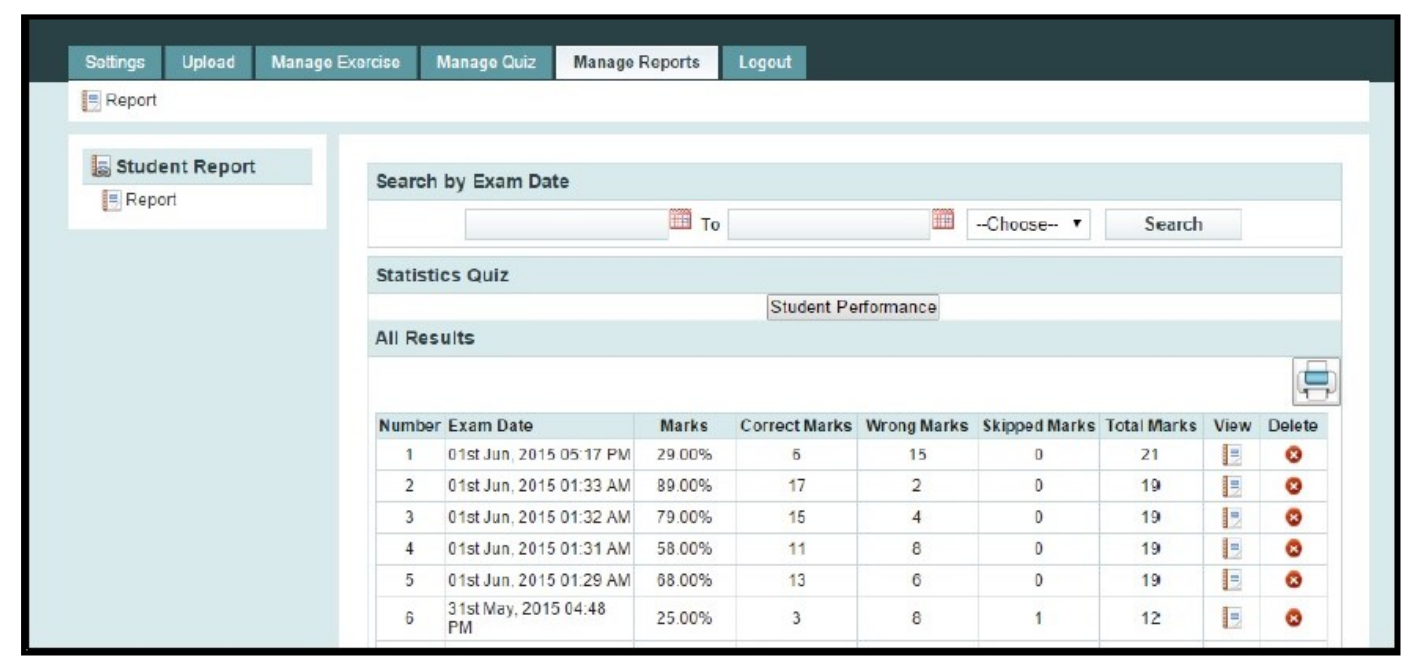

Figure 4: Teacher managing students' assessment report

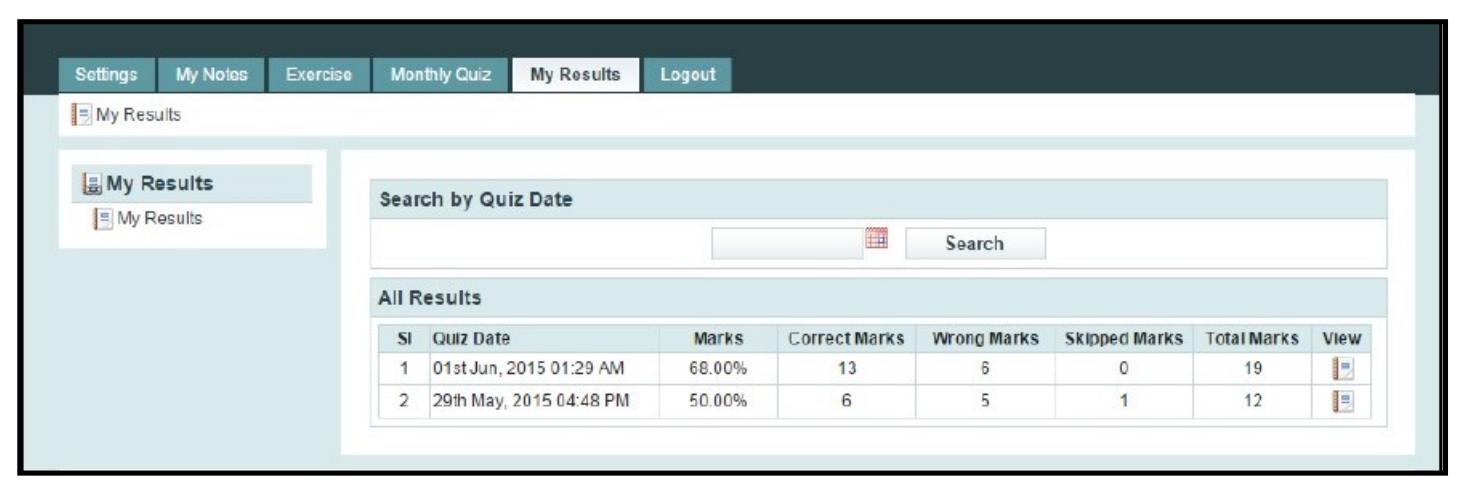

Figure 5: Interface for students viewing their own assessments result

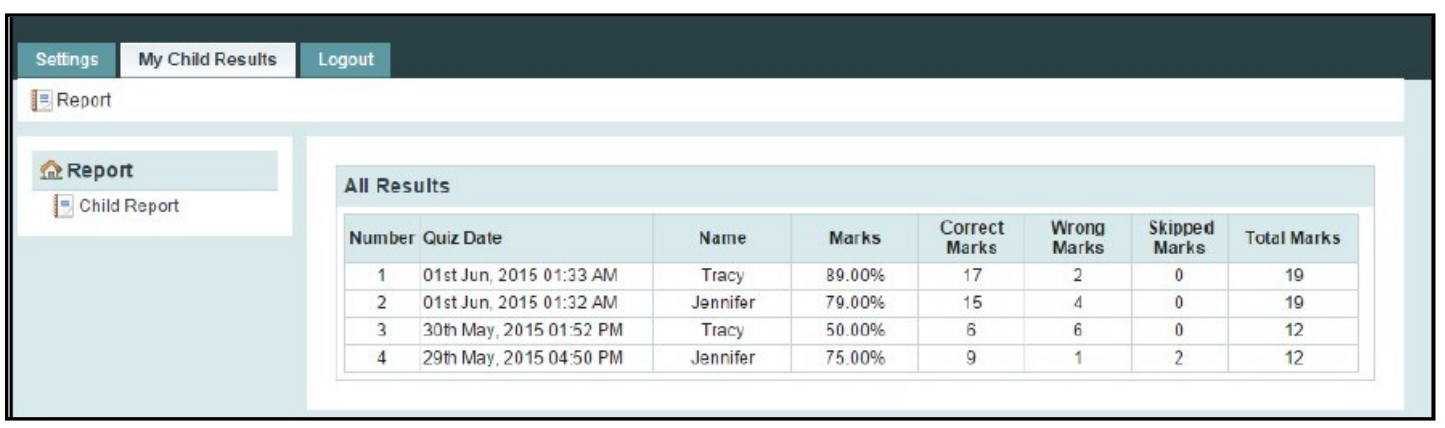

Figure 6: Interface for parents viewing their children assessment results 


\section{Implementation and Testing}

Implementation and testing phases play a role to test the functionality of the system in order to ensure that the systems developed, meet the needs of the design mentioned previously. Implementation and testing phases also ensure that all the processes involved in the system are functioning properly. The implementation phase consists of design interface, writing system coding and documentation.

\section{A. System Implementation}

The Implementation Phase described how the information system is deployed, installed and transitioned into an operational system. At the end of the implementation phase, the result is evaluated according to the list of requirements created earlier. The system also will be evaluated according to the design. This phase is complete when all of the requirements have been met and when the result corresponds to the design.

\section{B. Functional Testing}

Functional testing was conducted to examine the functionality of all the module created in the system. This testing involved user input and output where during this process all the error will be reviewed and fixed. In order to ensure the system functionality testing was correctly done, a test plan was divided into three user level which are admin, teacher and student. Table 1 shows the validation for the administrator site. The admin module consists of managing user account, learning module material, test bank and student class groups. Table 2 shows the test plan for parent module where parent should be able to change their password, view children details and view children assessment report. Table 3 shows the test plan for student module and Table 4 shows test plan for teacher module. Student test plan are based on whether students are able to update profiles, download learning materials, submits assessment answer and view their results. Teacher unit testing plan are based on where users are able to upload, create, edit and delete questions, setting the exercise time range and view students' performance.

Table 1. Unit testing of test plan for admin module

\begin{tabular}{lll}
\hline Test cases & Expected output & Actual output \\
\hline Click manage user & $\begin{array}{l}\text { Register teacher and } \\
\text { student, able to edit user }\end{array}$ & $\begin{array}{l}\text { The manage user is } \\
\text { initiated }\end{array}$ \\
Click view feedback & View public feedback & $\begin{array}{l}\text { The feedback is } \\
\text { initiated }\end{array}$ \\
\hline
\end{tabular}

Table 2. Unit testing of test plan for parents module

\begin{tabular}{lll}
\hline Test cases & Expected output & Actual output \\
\hline Change password & Password changed & Password change \\
View children details & Children details viewed & $\begin{array}{l}\text { Children details } \\
\text { viewed }\end{array}$ \\
$\begin{array}{l}\text { View children } \\
\text { assessment report }\end{array}$ & Assessment report viewed & $\begin{array}{l}\text { Assessment report } \\
\text { viewed }\end{array}$ \\
\hline
\end{tabular}

Table 3. Unit testing of test plan for student module

\begin{tabular}{|c|c|c|}
\hline Test cases & Expected output & Actual output \\
\hline Student profile updated. & $\begin{array}{l}\text { Update the } \\
\text { information. }\end{array}$ & $\begin{array}{l}\text { Student profile } \\
\text { updated. }\end{array}$ \\
\hline $\begin{array}{l}\text { Download } \\
\text { material files. }\end{array}$ & Files downloaded. & Files download. \\
\hline $\begin{array}{l}\text { Submitted assessment } \\
\text { answer. }\end{array}$ & $\begin{array}{l}\text { Assessment answer save } \\
\text { into databases system. }\end{array}$ & $\begin{array}{l}\text { Assessment } \\
\text { answer added. }\end{array}$ \\
\hline Download button. & Files downloaded. & Files downloaded. \\
\hline $\begin{array}{l}\text { Question button to do all } \\
\text { the exercises. }\end{array}$ & $\begin{array}{l}\text { Exercise displayed and } \\
\text { time set. }\end{array}$ & $\begin{array}{l}\text { Exercise displayed } \\
\text { and time set. }\end{array}$ \\
\hline View the result. & Result review. & Result review. \\
\hline
\end{tabular}

Table 4. Unit testing of test plan for teacher module

\begin{tabular}{|c|c|c|}
\hline Test cases & Expected output & Actual output \\
\hline Teacher profile updated. & $\begin{array}{l}\text { Updated the new } \\
\text { information. }\end{array}$ & $\begin{array}{l}\text { Teacher profile } \\
\text { updated. }\end{array}$ \\
\hline $\begin{array}{l}\text { Search student by group } \\
\text { and session. }\end{array}$ & $\begin{array}{l}\text { Display student by class } \\
\text { group and session. }\end{array}$ & $\begin{array}{l}\text { The student list by } \\
\text { group and session } \\
\text { is initiated. }\end{array}$ \\
\hline View student list profile. & $\begin{array}{ll}\text { Display } & \text { registered } \\
\text { student list and profile. }\end{array}$ & $\begin{array}{l}\text { The student list and } \\
\text { profile is initiated. }\end{array}$ \\
\hline $\begin{array}{l}\text { Upload learning material } \\
\text { files. }\end{array}$ & Files uploaded. & Files uploaded. \\
\hline $\begin{array}{l}\text { Manage student } \\
\text { assessment answer. }\end{array}$ & $\begin{array}{l}\text { Marking student } \\
\text { assessment answer. }\end{array}$ & $\begin{array}{l}\text { Assessment answer } \\
\text { marked. }\end{array}$ \\
\hline Click generate mark. & Student assessment mark. & $\begin{array}{l}\text { Assessment mark } \\
\text { generated. }\end{array}$ \\
\hline Save student mark. & $\begin{array}{l}\text { Added student mark into } \\
\text { database. }\end{array}$ & $\begin{array}{l}\text { Students } \\
\text { recorded. }\end{array}$ \\
\hline $\begin{array}{l}\text { Add, delete and update } \\
\text { learning material files. }\end{array}$ & $\begin{array}{l}\text { Learning material added, } \\
\text { deleted and updated }\end{array}$ & $\begin{array}{l}\text { Learning material } \\
\text { added, deleted and } \\
\text { updated }\end{array}$ \\
\hline
\end{tabular}

\section{Evaluation}

In order to validate the performance of the proposed system, user acceptance testing (UAT) been carried out through questionnaire distributed among the user. UAT is important phase in this study as to validate the capability of the software in handling required tasks in real world scenarios. The testing was conducted by 1 admin and 1 teacher in the Minda Proactive Tuition Center and 20 students. The implementation of system testing is successfully conducted. The actual outputs are similar to the expected results. Comments and suggestions from the user acceptance testing are gathered and adopted to improve the system in the future. Figure 6 shows the number of satisfied user with reference to system interface design.

Figure 7 showed result for six interface design questions answered by 22 user with scale 1 (least agree) to 5 (strongly agree). The question are based on homepage design, text and button style, text color, background color, interface design and level of user friendliness. From Figure 7, it shown that most user agree and strongly agree with the system design interface 
and none of the user disagree and strongly disagree with the design interface.

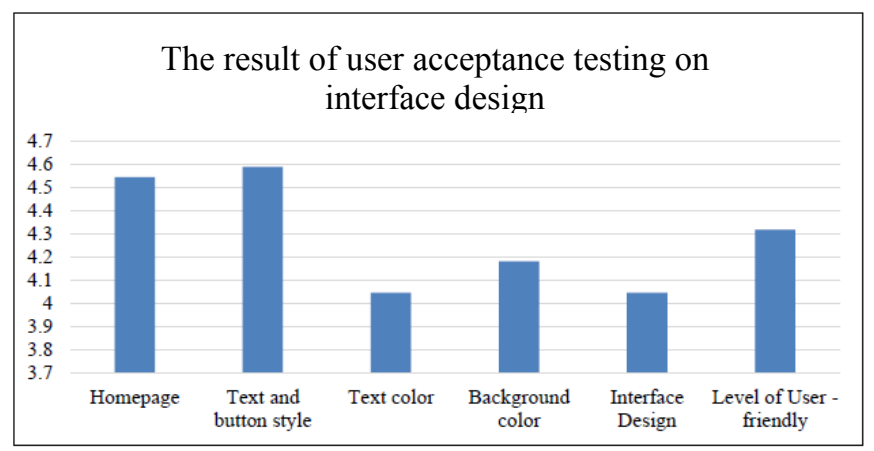

Figure 7: Result of user acceptance test on interface design

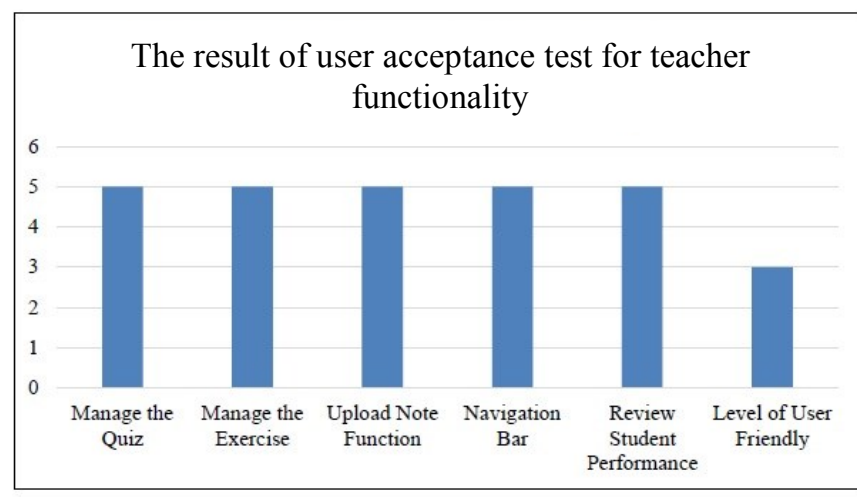

Figure 8: Result of user acceptance test for teacher functionality

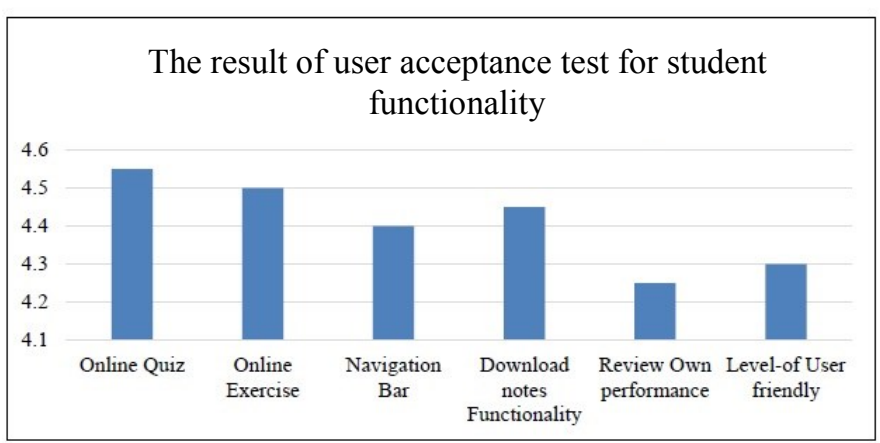

Figure 9: Result of user acceptance test for student functionality

From Figure 8, it shows the number of satisfied user according to the teacher functionality. It showed result for six function with scale 1 (weak) to 5 (very good). The tested aspects are; manage quiz, manage exercise, upload learning material, navigation bar aspect, review student performance and level of user friendliness.Besides, Figure 8 show that most user agree and strongly agree with the system functionality and none of the user disagree and strongly disagree with the functionality. Figure 9 shows the number of satisfied user according to the student functionality. It showed result for six function answered by 20 user with scale 1 (weak) to 5 (very good). The tested aspects are on online quiz, online exercise, on navigation bar, downloading learning material functionality, review their own performance and level of user friendliness. From Figure 9 , it shown that most user agree and strongly agree with the system functionality and none of the user disagree and strongly disagree with the functionality.

\section{Conclusion}

E-Learning Tutoring System for SPM English was developed in assisting secondary school student in learning English using alternatives ways through web platform. It can be used by any students who are interested in English subject. Furthermore it helped in student in tracing and comparing their result while doing quiz through this e-learning system. Although this system has been successfully developed, it still can be enhanced for instances adding more interactive components such as videos as learning material. SMS notification for parents should be one of the improvements that will make the information of their children delivered faster rather than email notification. This improvement can also be applied in the future to produce a more functional and useful system, yet easy to use and more compatible. In conclusion, it is hope that this research will contribute to education domain particularly in SPM English subjects and it will reap the benefit from e-learning approach.

\section{Acknowledgement}

This paper has been supported by, Short Term Grant, Universiti Tun Hussein Onn Malaysia (UTHM) (vot U539) for the financial support. This research also supported by GATES IT Solution Sdn. Bhd under its publication scheme.

\section{References}

1. D. Zhang, J. L. Zhao, L. Zhou and J. F., Nunamaker Jr, "Can e-learning replace classroom learning?", Communication of the ACM, 47(5), 75-79, (2004).

2. D. Tavangarian, M. E., Leypold, K. Nolting, M. Roser and D. Voigt, "Is e-learning the solution for individual learning", Electronic Journal of ELearning, 2(2), 273-280, (2004).

3. C. L. Goi and P. Y. Ng, "E-learning in Malaysia: Success factors in implementing e-learning program", Journal of Int J Teach Learn Higher Education 20(2) 237-46, (2009).

4. http://digitallearning.eletsonline.com/2008/11/tracin g-e-learning-initiatives-in-malaysian-schools-2/ access on 27/03/17.

5. J. Thirunsaku and M. Y. Melur, "The Many Faces of Malaysian English", International Scholarly Research Network, 2012.English language issues in Malaysia revisited,

https:/www.malaysiakini.com/letters/306589\#ixzz4 cniS7Rd1, access on 27/3/2017

6. Dennis, A. Roth, R. M. and Wixom, B. H. "System Analysis and Design", $5^{\text {th }}$ Edition, Wiley, (2013) 